\title{
Value Creation in Experience-Based Networks: A Case Study of Sport-Events in Europe
}

\author{
Nina Katrine Prebensen \\ Tromsø University Business School, Tromsø \\ Norway
}

\section{Introduction}

Sporting events struggle to be economically, socially, and environmentally sustainable (Pitts and Stotlar, 2002), either through favourable business conditions (Porter, 1980) or through their internal resources and capabilities (Wernerfelt, 1984; Barney, 1991). To deal with these challenges, organisations tend to turn to cooperation and networking (Achrol, 1997; Achrol \& Kotler, 1999; Dyer and Singh, 1998; Nohria \& Zaheer, 2000; 2006). In particular, Gulati (1999: 399) claims that a firm's network might offer 'network resources that are the source of valuable information for firms.' An example of such resources is the building of routines for sharing knowledge to enhance values when any firm in isolation cannot generate the value (Dyer \& Singh 1998; Möller and Rajala 2007; Gulati 1999). Despite this increase in interest and knowledge regarding value creation in networks, especially for sporting events (e.g., Prebensen, 2010), few studies have actually explored how and why these networks come into existence. Consequently, this chapter explores business nets, e.g., sporting events, with particular focus on the network structure and the purpose of participating in the network. The research questions are: how and why do organizations, e.g., sporting events, cooperate in a network?

Cooperating and co-creating values within the purview of sporting events deals with generating experience value through network interactions (e.g. Achrol \& Kotler, 2006; Grönroos, 2006; Gummeson, 2006). Athletes come together to compete, more or less for fun and perhaps also for monetary purposes, and the spectators come to see and applaud their performances. However, people and organizations join these events for numerous other reasons as well (Holt, 1995). And, the more capable and popular the athletes or the events become, the more instrumental the reasons for attending the event are likely to be. Skills and popularity bring more spectators to the scene. More spectators bring more economic value to the event and, along with interest and money, sponsors and media are attracted. As a result, the events become more professionalized and some of them become regular market-based companies (i.e., ltd). The popularity of sporting events has been enhanced by the increase and ease of worldwide communications and transportation (Chalip, Green \& VanderVelden, 2000; Delpy \& Bosetti, 1998; Schaaf, 1997). Along with this trend, sponsors and the media anticipate vast market potential for their offerings (Trail, Fink \& Anderson 2003). Sporting events offer strong emotional value to the spectators (Cialdini, 2000) and help to promote subsequent business propositions for the events and their stakeholders (Prebensen, 2007). 
Research recognises that value is something that is created between different actors (Vargo \& Lush, 2004). Vargo and Lush point to the significance of focusing on people and interaction in value creation. In the evolving service-dominant (S-L) logic the concept of cocreation is defined as a process of cooperation between actors where all actors take active parts in creating value (Vargo \& Lush, 2004; 2006). An organization then depends on its stakeholders and their commitment to creating values for the company and for themselves. Relations and networks thus might facilitate and restrain the organisations' ability to perform (Wilkinson, 2008). Relations and networks hence play basic roles in "assessing, combining, recombining and coordinating the activities, resources and outputs of people and firms" (Wilkinson, 2008: 23), and "are the means by which the knowledge, skills and resources required to develop, exploit and commercialise new ideas are marshalled and coordinated" (Wilkinson, 2008: 25). Consequently, networks are essential for most organisations in that they create values.

Sporting events vary in terms of size and economic strength. Some are global; others national or local. For smaller and rural sporting events that are struggling to be economically sound, networking might be of particular strategic value. The most evident reason for cooperation and networking is to promote the sport itself and to augment publicity. More interest and attraction regarding a certain type of sport gives the pertinent events a market potential. Another apparent reason for networking would be knowledge sharing between the organizations. For sporting events, this might include knowledge regarding how to organize and structure the event, what spin-offs could be developed, how to motivate and organize voluntary workers, and how to develop an economically and environmentally sound organization.

An event may attract local, regional, national and even international spectators, depending of its uniqueness, status and promotion. For example, an event might supplement the tourism industry by functioning as an attraction for visitors. Getz (1997: 338) portrays event tourism as "the systematic planning, development, and marketing of festivals and special events as investor attractions, development catalysts, and image builders for attractions and destination areas". Sporting events, as part of the concept of special events, attract visitors and other stakeholders because they are perceived as unique and different from other types of attractions (Getz, 1989). Destinations might benefit economically from events in that the events attract visitors. Addressing the process of co-creating successful events through networking and cooperation with organizers of similar events would help tourism marketers in their work of attracting visitors to the destination and would add value to positioning and branding strategies for destinations.

Research that explores why people attend various events is increasing (e.g., Nicholson and Pearce, 2001; Prebensen 2010). Consumer research literature has in general begun to view consumption not only as rational decision-making, but as a more multi-sensory activity in which emotion and fantasy play important roles (Holbrook and Hirschman 1982). Business research, i.e., Allen and McGoun (2000) and Prebensen (2007), has adopted some of the thoughts from consumer research (Holt 1995) and explored investors' motivations for investing in various businesses. These authors employ Holt's (1995) typology of consumption practices, which uses the purpose of the action and the structure of the action as the basis for a theoretical study. The present study attempts to follow these ideas and utilizes Holt's consumer behavior matrix on networking in sporting 
events. The present work employs a network of five different sporting events, all dog-sled races in Europe, as a case study to exemplify value co-creation activities in network (c.f., Van Limburg, 2009; Prebensen, 2010). The goal is to identify value creation by analyzing why and how the events participate in a network to co-create values for themselves and others. Consequently this paper seeks to arrive at a new understanding for value creation in a network framework.

In this chapter relevant theories regarding value creation in networks will be put forward. In particular, theories on the topics of stakeholder, cooperation, relations, business nets and motivation for entering networks will be defined and outlined. The author also turns to consumer behaviour literature (Holt 1995) to reveal how and why these firms cooperate through networks. The reason for utilizing this theory as a framework for acknowledging network processes is that people in these organizations might have various purposes and strategies, for the organization as well as for themselves, in joining these networks. Then the case and the study method are put forward. Next the results are delineated, followed by discussions and conclusions.

\section{Network as mediator in value creation processes}

Based on Freeman's (1994) seminal work on stakeholders and networks, Galaskiewics (1996) describes network research as "a handmaiden theory", since it is often employed to validate other theories but seldom becomes the focus of its own progress. Values are created within organisations by people. Correspondingly, theories about stakeholders have been used in research concerning organisations (March \& Simon, 1958) and business managers (Mason \& Mitroff, 1981). Freeman (1984: 25) defines a stakeholder as "any group or individual who can affect or is affected by the achievement of the firm's objectives". Researchers have adopted Freeman's definition and propose a variety of viewpoints. Carrol (1993) suggests for instance that the ability to impact the organisation is the more relevant issue. Clarkson (1995) views the stakeholder as a party who holds authority and/or some resources, i.e., financial resources, human resources, or knowledge which may influence the outcome for the stakeholder in a positive or negative way. Groups normally referred to as stakeholders include employees, customers, local communities, governments, and shareholders. However, stakeholders might also represent competing organisations aiming to cooperate in networking (e.g., Gummeson 2002). The main focus of the present work is why and how values are created in a network of competing and/or cooperating firms. As such the Freeman (1984) definition of stakeholders' is significant.

Networking deals with cooperation between people and organisations. Cooperation is defined by Anderson and Narus (1990: 45) as "similar or complementary coordinated actions taken by firms in an interdependent relationship to achieve mutual or singular outcomes with expected reciprocation over time." Cooperation and networking embody the willingness of stakeholders to build a relationship (Nielson \& Wilson, 1994). Cooperation has been conceptualized to include dimensions such as: resource/information sharing, joint action, and harmony and flexibility (Heide \& John, 1988; Noordewier \& Nevin, 1990; Nielson \& Wilson, 1994).

Cultural differences might exist when people and events from different countries aim to cooperate, and as a result difficulties of communication and information sharing could be a major barrier to business (Terpsta \& David, 1985). In addition, cultural differences might 
be due to the various ways of financing the event organisation. Some organizations are privately-owned entities while others are public- or project-based. The success of a privately-owned company might have more to do with economic surplus than would be the case for public companies and projects that do not need to focus on income and profits to the same extent.

In a network of five events, the development of interpersonal relationships is shown to improve overall commitment to the network (Mummalaneni \& Wilson, 1991). Rylander, Strutton and Pelton (1997) claim that commitment, to a great extent, takes place at a personal level. Commitment is described in literature as "the desire to continue the relationship and ensure its continuance" (Wilson, 1995: 337) and "an implicit or explicit pledge of relational continuity between exchange partners" (Dwyer \& Schurr, 1987: 19). Commitment is further depicted to include three components: instrumental, attitudinal and temporal commitment (Brown \& Lusch, 1995; Gundlach, Achrol \& Mentzer, 1995; Kumar, Scheer \& Steenkamp, 1995; Kim and Frazier, 1997). While instrumental commitment deals with economic needs, the attitudinal component represents a continuing intent by parties with some normative or affective attachment to sustain an enduring long-term relationship (Brown et al., 1995; Kim and Frazier, 1997). The temporal commitment deals with long-term relationships in which the stakeholders become more profoundly involved in the relationship (Gundlach et al., 1995; Kim and Frazier, 1997). When people meet they might develop friendships, defined as social bonds, where emotional elements are recognised (Wilson, 1995: 339). Social bonding is also revealed to support the existence of shared values, which leads to an increase in trust and a decrease in opportunism (Morgan and Hunt, 1994).

In addition to commitment, efficient networks and relationships are based on loyalty and trust (Blau, 1964; Zaheer, McEvily \& Perrone, 1998). Interpersonal trust is defined by Rotter (1967: 651) as "an expectancy held by an individual or a group that the word, promise, verbal or written statement of another individual or group can be relied upon." The literature also describes trust as a construct in terms of reliability, integrity, competence, honesty, fairness, responsibility, helpfulness, and confidence (Moorman, Deshpande \& Zaltman, 1993; Morgan and Hunt, 1994). Trust is further depicted to reduce opportunistic behaviour (Morgan and Hunt, 1994).

Studies also point to the importance of personal relationships in networking (Granovetter, 1985; Uzzi, 1997). Recent research (Pesamaa \& Hair, 2007) shows the importance of longterm relationships to friendship, loyalty, commitment and trust, and that commitment and trust are paramount in stimulating successful cooperation. While Blau (1964) claims that cooperation is based on personal relations, Gulati (1995) holds that firms evaluate the relative importance of their options based on previous experience. The most impelling reason for cooperation and networking, however, is that there is something in it for each stakeholder. The reciprocity, i.e., the practice of give and take with a network, is pictured as vital (Portes, 1998). Mavondo and Rodrigo (2001) discuss the idea of norms of exchange where the individuals feel obligated to return favours.

\section{Network motivations}

As reciprocity in a network deals with give and take, the fundamental motivation for joining a network is to receive a fair portion of the synergistic effects that are created. In a situation where competing sporting events and organisations create a network, goals and motives are 
expected to diverge among the stakeholders. An obvious goal for all stakeholders would, however, most probably deal with strengthening the public awareness of and interest in the sport in general, e.g., dog-sledding, and as such result in a win-win situation for all stakeholders.. Other goals might include knowledge sharing and learning to help the respective events become more sustainable. These goals are instrumental ones, and the network provides the means to attain them.

Knowledge creation and sharing have a positive revenue side, but they also include possible costs to the stakeholders. When competing sporting events share knowledge, there is a risk that some stakeholders will gain more and some will gain less knowledge, i.e., the risk of having the value of their knowledge transferred to other stakeholders reduces the value of their knowledge in the marketplace (i.e., decrease of relative attractiveness with athletes, sponsors, and media). Therefore, to achieve a win-win situation for competing events in terms of knowledge sharing, the focus should be on developing sustainable advantages for all stakeholders. To achieve sustainable advantages for all stakeholders should be brought to the network table by each stakeholder. To ensure value creation for all stakeholders in a network it is important to reveal the purpose of participation, what values (type and valence) they expect from the cooperation, and how (with what resources) they should participate in the network (e.g. Fyall et al., 2003). This would increase the network loyalty and prevent some stakeholders from only tapping resources from the network without providing something back.

Value as a business concept has received significant attention in marketing and management literatures. Ulaga and Eggert (2005) identify four characteristics of perceived value: (1) value is a subjective concept, (2) it is conceptualized as a trade-off between benefits and sacrifices, (3) benefits and sacrifices can be multifaceted, and (4) value perceptions are relative to competition. Based on these four characteristics Ulaga and Eggert summarize that "... value is defined as the trade-off between the benefits and the sacrifices in a market exchange". According to these scholars, the main purpose of a sporting event network should be to focus on defining who their customers or stakeholders are, and then deliver expected value in the marketplace. However, a simple focus on value for customers or stakeholders might lose some important perspectives, i.e., value created in and within organisations and networks might be ignored. In particular, value creation as a result of sharing capabilities and competencies in networks might be neglected.

\section{The Holt (1995) model within a sporting event network perspective}

Holt (1995: 1) asks "what do people do when they consume". Based on Holts (1995) this chapter presents a typology of consumption practices, based on the purpose of the action and the structure of the action (see figure 1 and the subsequent description below). The Holt (1995) model has been discussed in other empirical settings, e.g., investments (Allen \& McGoun, 2000; Prebensen, 2007). Viewed with the perspective of these works and with the theoretical discussion above regarding business networks, the present chapter utilizes Holt (1995) as a framework for analyzing organizations, structures and purposes in a network context. The focus is on the action of the actors in the network itself.

The figure shows a typology of consumption practices, named as experiencing, integration, play and classification, which are based on the purpose and the structure of the action. The model is described as follows. The purpose of the action deals with "autotelic" and 
"instrumental" actions, while the structure of the action includes actions towards objects or people. Holt presents a model of spectator consumption practices based on thorough explorative research of professional baseball. When spectators make sense of and respond to the sport in itself (autotelic/object action), Holt describes them with a "consuming-asexperience" metaphor. The spectators use various interpretive frameworks to experience baseball; through accounting, evaluating and appreciating the event. In contrast with consuming-as-experience, "consume-as-integration" (instrumental/object action), is about the spectators' use of the sporting event as an instrument to enhance their identity. Integrating practices, i.e., assimilation, production, and personalization are used to break down distances between the consumer and the object. When a sporting event is used as a resource to interact with fellow spectators, the metaphor "consuming-as-play" (interpersonal/autotelic) is utilized. Among baseball spectators, two types of playing are prevalent,--communing and socializing. The fourth metaphor, "consuming-as-classification" (interpersonal/instrumental), refers to situations where the spectators use the event to classify themselves. Classifying practices provide the means to build affiliation and to enhance distinction, and the spectators do so through objects or through actions. Spectators often use symbols, i.e., clothing, and stories in order to classify themselves.

PURPOSE OF ACTION

\begin{tabular}{c|c|c|}
\multicolumn{1}{c}{} & \multicolumn{1}{c}{ Autotelic actions } & \multicolumn{1}{c|}{ Instrumental Actions } \\
\cline { 2 - 3 } $\begin{array}{c}\text { Object } \\
\text { Actions }\end{array}$ & $\begin{array}{c}\text { CONSUMING AS } \\
\text { EXPERIENCE }\end{array}$ & $\begin{array}{c}\text { CONSUMING AS } \\
\text { INTEGRATION }\end{array}$ \\
STRUCTURE OF ACTION & $\begin{array}{c}\text { CONSUMING AS } \\
\text { PLAY }\end{array}$ & $\begin{array}{c}\text { CONSUMING AS } \\
\text { CLASSIFICATION }\end{array}$ \\
\cline { 2 - 3 } & & \\
& &
\end{tabular}

Fig. 1. Metaphors for Consuming (Holt 1995: 3)

Network stakeholders (i.e., owners, mangers, board members, project leaders) would represent their organizations' goals and purposes (e.g., economic, social, environmental), but will also have their own interests in joining these networks (e.g., learning, meeting fellow representatives from other organizations, socializing, and gaining new contacts and acquaintances). Discovering why and how these stakeholders act the way they do would generate new knowledge of network theories and practices.

\section{Research approach}

The key stakeholders in the present study include the organizers of five sled-dog races in various places in Europe-- France, Sweden, Spain and Norway. The races are The Grand 
Odysee (France), La Pirena (Spain), The Amundsen race (Sweden and Norway), Finnmarksløpet (Norway), and Femundløpet (Norway). The organizers play various roles when participating in the network due to their type of organisation, economic strength, and how long they (number of years) have been organising the event, in addition to their motivation for cooperation and value creation for themselves and others.

Values for the respective events are mostly utilitarian, (i.e., economic, promotional and image-related ones). However, hedonic values might also come into existence, in that many of the organisers of the events are engaged due to the hedonic (fun and enjoyment) values of the event (c.f. Holbrook and Hirchmann 1982). These value dimensions might also influence overall perceptions of a local community and its identity (among locals) and destination image (e.g., among potential visitors), and are often part of a regional plan and/or may be sponsored by the local community. In the present work we identify key stakeholders in the network as management, project leaders, owners and/or members of boards of directors representing the respective events. Our primary focus is on their networking activities.

\section{Study methods, data collection and data analysis}

To explore why and how organizations co-create values in networks, the present study has adopted the Holt (1995) model as a framework. Holt (1995) utilized a constructionist and an integrationist approach in his research. Cooperation and networking are viewed in the present research as a type of social action in which people make use of objects in a variety of ways (Simmel, 1950).

Given the lack of empirical research of stakeholders' participation in value creation in networks of sporting events, this research is exploratory. Consequently, in selecting an appropriate research method, the in-depth analysis found in qualitative research seems most suitable to enhance understanding of value creation in the network context. We chose this method because it acknowledges how actors construct and interact within their social world, which should be thought of as individually constructed and interpreted (Altheide \& Jonson, 1994). However, qualitative techniques might explore varying depths (Prebensen, 2007), calling for multiple qualitative perspectives as well.

To explore what people and organizations in fact are doing when they are cooperating in a network of sporting events, several methodological parameters had to be chosen. First, the empirical setting was selected. Since the concept is complex and highly sensitive to social and situational context (Markus and Nurius 1986) this present work required a research method with the ability to phenomenologically explore the thoughts, feelings, and behaviors of informants, and to capture and account for the social and situational context of phenomena. The present research is therefore based on various qualitative techniques -participating observation and discussions during a two-day symposium in Paris, France at the "International Sled Dog Race Organizer Symposium", personal interviews with some of the representatives in the symposium, and group discussions. To get a detailed understanding of experiences among the representatives of the sporting events cooperating in this particular network, informal discussions with the stakeholders were conducted and participating observations were made during the two-day conference/meeting of the representatives. Due to the informal nature of the conversations and discussions, recording them seemed impractical. However, regular notes were written in the research journal as soon as possible following the conversations and the symposium. In addition, relevant 
material was collected from web pages, newspapers and television reports to get a more complete portrayal of the phenomenon. When analyzing the data all notes and transcripts were thoroughly examined. In particular, the descriptions of critical incidents, information and comments that were mentioned repeatedly were highlighted. The objective was to recognize and acquire new knowledge about the interaction process and the variety of purposes for building networks. The personal discussions, free talks and presentations during the symposium, by acknowledging the personal relationships between the stakeholders, ensured a better understanding of the task of establishing the validity of the stakeholders' relationships and of the networking proposition as a whole.

Second, the number and type of stakeholders was chosen. Each of the five sporting events , represented by one, two or three persons (managers and/or owners), participated in the symposium and the discussions for the purpose of fully exploring the topic. During the breaks and after the symposium, they were asked about their motivations for participating in this network. When analyzed, different interaction experience types were found. These were based on the stakeholders' motives and interaction.

Third, stakeholders (persons representing all five sporting events), were purposely selected to provide insight into important relationship phenomena in this stage of the research (Erlandson, Harris \& Skipper, 1993). The network group (symposium) representing the five events included eighteen people, five women and thirteen men, ranging in age from $25-65$ years. Only seven of these people, however, were included in the personal discussions. Storytelling about various incidents was the primary focus of the discussions.

The author of the present chapter has been working as a volunteer for one of the races, the Finnmarksløpet. In addition, she has been a shareholder of the company since the foundation of the business in 2001, has been part of the board for 8 years, and has held the position of director of the board from 2005 until 2009. Due to her personal involvement in one of the races, the knowledge received from this learning process must be handled with care. Still, the data are definitely valuable for in-depth understanding of the phenomena being studied, namely stakeholder participation in value creation in a network.

\section{Results}

\subsection{Networking-as-experience}

The "networking-as-experience" metaphor is about people's subjective and emotional reactions to an object related to cooperation in the network, and is seen as a psychological/emotional state of mind. These reactions include different levels of arousal and different types of emotional states, depending on the type of network, the level of risk felt, the degree of involvement in the cooperation, and situational factors as well as personality traits. One might reasonably assume that the co-operative process in sporting event-based networks would have its own specific set of working assumptions. In that this is only the second time the symposium has been held, the network is rather new and still developing with many new ideas being put forward. The stakeholders make sense of the risks (time and effort) when entering a network arena. They employ their cognitive schemata and heuristics in the situation to make sense of or compare situations (Simon, 1960; Schwenk, 1988). The stakeholders of the present network perceive themselves as more or less risk averse (i.e., if they intentionally avoid risks or not), depending on their position 
in the subsequent event and the type of organization that the event is founded on. Out of the five events in the study, three are based on traditional business ownership and include investors (ltd). The other two events are more volunteer-based and are run by local or regional foundations. Shareholders in ltd-based events seem to be more risk-averse than those running other types of organizations. However, the content of risk must be regarded as having various meanings, e.g. economic risk, social risk, or physical risk (e.g. Peter and Olson 1996). To participate in this type of network, monetary risk is rather low. Spending time and sharing knowledge seem however to be at issue for most representatives.

The stakeholders were invited to the symposium and the meeting to discuss potential cooperation, independent of their size and economic strength. They also varied in terms of experience, knowledge and strategic skills. One of the main issues in the symposium was to get a common understanding of the situation of the sport and how the network could better promote the sport and in so doing bring more attraction and interest to all events. The process of experiencing the network includes "accounting, evaluating, and appreciating" (Holt 1995). For some of the stakeholders, accounting and evaluating involved discussing possible outcomes of networking (more than just financially) with other stakeholders. Strategic discussions for the single events as well as for the destination seemed to be the focus. In particular, questions such as choosing the right profile for sport as a whole, and for the single events separately (so as not to copy each other) were common. The stakeholders tried to structure and understand the strengths and weaknesses of each race to find potential business propositions and values (possibilities and faults) of the event. They also responded to various ideas and proposals regarding product developments, etc. The network represented by the present symposium offered the stakeholders an arena in which to meet and to discuss future developments. The informants articulated that meeting the other stakeholders personally and getting to know each other was very important to feeling comfortable and to increasing trust in and commitment to the network (e.g., Morgan and Hunt 1994). In addition, they often referred to the feeling of being part of a team as valuable. Social identity theory (e.g. Tajfel, 1981) argues that there are two distinct aspects of the "self": personal identity and social identity (collective identity). The self is defined as the "totality of the thoughts and feelings that have reference to the self as an object" (Rosenberg, 1979). In this sense the network gives the stakeholder a type of "value" that enhances the personal and group identity. The event can thus function as a means for building identity for the individual representing the network as well as for the event he or she represents.

\subsection{Networking as integration}

"Networking-as-integration" is a metaphor that reflects what the stakeholders do when they acquire and manipulate object meanings. Network experience, such as talking to other stakeholders, impacts the stakeholder's integration process. Knowledge is often a key to enhance value in networks (Gulati, 1999) and might influence the stakeholder's motivation to participate in the network in addition to their perceived identity as part of the network. Some would use their experience to share knowledge with others, while others would try to learn to improve their skills regarding sporting events. In this line of reasoning there is also a matter of reciprocity, the practice of give and take (Pesämaa, Hair \& Jonsson-Kvist, 2007) which often develops norms of exchange by making individuals feel obligated to return favours (Mavondo \& Rodrigo, 2001). Within these cooperating and networking conditions and processes people often have a need to feel in control of their own lives (Skinner, 1995). 
Individuals need to feel that they can avoid undesired occurrences and create desired ones, and can influence their own and others' behaviour, emotion, and motivation under conditions of challenge. One example might be how stakeholders say that they wish to avoid unserious stakeholders who want to participate in the network. Control of who to network with (other stakeholders) seems to be of importance. Individuals also create value within the group by discussing business propositions "maybe we can develop a championship cup between mushers participating in several of the sled dog events?" People adopt various roles depending on the context. Roles taken and/or given are socially defined and shared expectations of behaviour for an individual in a particular position. For example, during the "free talks" in the symposium, some stakeholders expressed new ideas and information, based on their event's position and strength.

The most compelling result is that the companies in the network agree that they want to build up and establish a high quality image of the dog-sledding sport all over the world. The stakeholders discussed, for instance, how they could inform the general public regarding how the dogs' health and wellness are provided for, and that they want to improve and coordinate rules and policies regarding the dogs' welfare across international borders. The results are thus in line with the findings of Chetty and Wilson (2003) that companies rely on reputation-related resources such as international image and the credibility of the cooperating competitor in the internationalization process. A central question discussed among the stakeholders is if the network could function to build a stronger image or at least promote dog-sledding as a sport. In these discussions, the stakeholders who had been working with and within the larger events for some years were to a certain degree given the role of "expert". Further, people with the longest or "most interesting" dog-sledding history seemed also to assume the role of an "expert" (e.g., veterinarians with long term experience with dog-sledding). Those with a veterinary background influenced the discussion towards focusing on the wellness and healthiness of the dogs before, during and after the competition. Clearly certain "dog-related" knowledge enhanced individual status and power in the network.

\subsection{Networking as play}

The "networking-as-play" metaphor includes interpersonal autotelic actions among the stakeholders. The stakeholders communicate and socialize when deciding to unite in a sporting event network. They smile, nod and converse with other stakeholders, thus showing how they feel about the relationship and the situation. Hinde (1995) in Prebensen (2007) suggest the following conditions of interpersonal relationships: 1) relationships involve shared exchange between active and interdependent relationship partners; 2) relationships are purposive, involving at their core the provision of meaning to the persons who engage in them; 3 ) relationships are multiplex phenomena: they range across several dimensions and take many forms, providing a range of possible benefits for their participants; and 4) relationships are process phenomena: they evolve and change over a series of interactions in the contextual environment. A sporting event might be equated with a theatre scene (Lovelock, 1995). Stakeholders take the role as audience or actors depending on the situation and the importance a stakeholder attributes to these roles. There are no accurate distinctions between the two different "roles". The stakeholders are "on stage" with the group they feel they belong to (in this case the organizers of other sporting-events). The degree of socializing seems to vary among the stakeholders. The reason for this variation 
seems to relate to the degree of time available and the strength of commitment among the stakeholders (Yoon, Baker \& Ko, 1994).

In tourism, special sights or attractions can attain the status of an "icon" by being perceived as rare, authentic, a marker, etc. (Dann, 1997; Leiper, 1990; Gunn, 1988; MacCannel, 1976). Sporting events could assume the status of an icon, especially if they are rare or of particular interest to the spectators.

\subsection{Networking as classification}

"Networking-as-classification" reflects the research that focuses on how stakeholders perform in networks. The stakeholders, the informants in the present work, were quite relaxed concerning the fact that they are stakeholders for a special sporting event. They see it as a type of engagement in something positive going on in their area, e.g. product development and profiling the area through various activities. However, there seems to be a division between those engaged in businesses and those representing a less formal organization or a region. Those who represent a region or a destination, i.e., a project, seem to use the network as a means to get hold of new projects. Those with a focus on one sporting event seem to be more concerned with the organization's economic situation. All stakeholders subscribe to the idea of being in the network for reasons such as establishing relationships and acquiring knowledge for future achievements.

One of the stakeholders claimed that learning about how to run an event business was one of the main purposes of participating in the network. This stakeholder hoped to use the knowledge gained in the network for organizing his own events as well as for other types of businesses- The different experience curves among the stakeholders seem to classify them as "professional" in two areas: with the sport "dog-sledding" or management and marketing knowledge in terms of running a business or a project. Another way of classifying the stakeholders was evaluating the strength of their relationships with other dog-sledding events, e.g., with the Iditarod in Alaska.

\section{Conclusion}

The present work shows that the typology suggested by Holt (1995) on consumption practices is well-suited for the analysis of business networks. By exploring the various stakeholders' purposes for participation in the network and the structure of participating, the results show that there are both economic- as well as non-economic-based actions. A central finding is that all five stakeholders recognize synergies beyond the receiving of new ideas and knowledge to create value for their own sporting event. They point to the fact that promoting the sport is the main goal which will benefit all stakeholders. Reciprocity is thus of importance, not only in terms of the single event, but also regarding promotion of the sport in general.

The findings of the study indicate a change in attitude among dog-sledding events in international competition. Through cooperation between competitors, the firms want to find and develop both practical and strategic international opportunities and thereby increase the attractiveness of the sport, generating business opportunities for the firms. The results further reveal that the different levels of cooperation affect the characteristics of international opportunities to some extent, i.e., business opportunities such as developing a 
championship cup versus increased attraction to the sport in general. The network relations have brought international opportunities for the companies and thereby may increase the awareness of the sport in general, enhance both competitiveness (European versus American continents), and value propositions for the respective events.

Furthermore, the various stakeholders participate in the event for somewhat different purposes and with diverse structures (strategies or way of behaving). The differences seem to be based on the following factors; 1 ) if the person is a shareholder of a sporting event that is organised as a business concept, 2 the degree and type of their experience, 3 ) the degree of reciprocity, 4) interpersonal commitment, and 5) loyalty to the network.

The results reveal that the representatives of the events in a network not only focus on the utilitarian and instrumental purposes of networking, but also on the hedonic and autotelic sides of being part of the network. Trust and commitment depend on interpersonal contact, which is shown to be of importance for business results as well. Further research on the relationship between interpersonal contacts in event networks should therefore be undertaken. Further research on network behaviour and motivation among event organizers should also be done, with a particular focus on the various phases that networks (initial versus maturing) might occupy. It would be valuable to further develop knowledge regarding the potential and, more importantly, the desirable combinations of different kinds of relations in an international context, regarding not only the strength of the relations but also their practical and strategic implications. Finally, a crucial topic for further research would be to investigate other sources and means for organizers to find and develop economically, socially and environmentally sustainable sporting events.

\section{Acknowledgement}

The author thanks the informants, the stakeholders of the five sporting events, for their participation in the study. The research in the present study is part of the research programme "Service Innovation and Tourist Experiences in the High North: The CoCreation of Values for Consumers, Firms and the Tourism Industry", financed by the Norwegian Research Association, project no. 195306/140.

\section{References}

Altheide, D., \& Jonsons, J. (1994). Validity in Qualitative Research. In N. Denzin \& Y. (Eds.), Lincoln handbook of qualitative research, Thousand Oaks: Sage, pp. 485-499.

Anderson, J.C, \& Narus, J.A. (1990). A Model of Distributor Firm \& manufacturer Firm Working Partnerships. Journal of Marketing (January), Vol.54, pp. 42-58.

Achrol, R.S. (1997). Changes in the Theory of Interorganizational Relations in Marketing: Toward a Network Paradigm. Journal of the Academy of Marketing Science, Vol.25(1), pp. 56-71.

Achrol, R.S. \& Kotler, P. (1999). Marketing in the Network Economy. Journal of Marketing, (Special Issue), Vol.63, pp. 146-163.

Allan, D.E. \& McGoun, E.G. (2000). Hedonic Investment. Financial Services Review. Vol.9, pp. 389-403.

Barney, J.B. (1991). Firm Resources and Sustained Competitive Advantage. Journal of Management, Vol.17, pp. 99-120. 
Blau, P.M. (1964). Exchange and Power in Social Life, John Wiley, New York, NY.

Brown, J.R, \& Lusch, R.F. (1995). Nicholson CY. Power and Relationship Commitment. Journal of Retail, Vol. 71(4): 3, pp. 63-92.

Carrol, A. (1993). Business and society: Ethics and Stakeholder Management. Cincinnati: South Western.

Chalip, L.; Green, C. \& VanderVelden, L. (2000). The Effects of Polysemic Structures on Olympic Viewing. International Journal of Sports Marketing and Sponsorship, Vol. 2 (1), pp. 23-34.

Chetty, S.K. \& Wilson, H.I.M. (2003). Collaborating with Competitors to Acquire Resources. International Business Review, Vol. 12 No. 1, pp. 61-81.

Cialdini, R.B. (2000). Influence: Science and practice, 4th ed. Boston: Allyn \& Bacon.

Clarkson, M. (1995). A Stakeholder Framework for Analyzing and Evaluating Corporate Social Performance. Academy of Management Review, Vol. 20, pp. 92-117.

Dann, G. (1997). The Tourist as a Metaphor of the Social World, Ed. UK: Cabi Publishing.

Delpy, L. \& Bosetti, H. (1998). Sport Management and Marketing via the World Wide Web. Sport Marketing Quarterly, Vol. 7 (1), pp. 21-6.

Dwyer, R.F.; Schurr, P.H. \& Oh, S. (1987). Developing Buyer-Seller Relationships. Journal of Marketing, Vol. 51(April), pp. 11-27.

Dyer, J.H. \& Sing, H. (1998). The Relational View: Cooperative Strategy and Sources of Interorganizational Competitive Advantage. Academy of Management Review, Vol. 23(4), pp. 660-679.

Elandson, D.A., Harris, E.L. \& Skipper, B.L. (1993) Doing Naturalistic Inquiry: Guide to Methods, Newbury Park, CA: Sage.

Flint, D.J.; Woodruff, R.B. \& Gardial, S.F. (2002). Exploring the Phenomenon of Customers' Desired Value Change in a Business-to-Business Context. Journal of Marketing, Vol. 66, pp. 1-30.

Freeman, R. (1984). Strategic Management: A Stakeholder Approach. Boston: Pitman.

Fyall, A., C. Callod and B. Edwards (2003) Relationship Marketing: The Challenge for destinations, Annals of Tourism Research, Vol. 30, No. 3, pp. 644-659, 2003

Galaskiewicz, J. (1996). The "New Network Analysis" and its Application to Organizational Theory and Behavior. In D. Iacobucci (Ed.), Networks in Marketing, Vol. 34, pp. 454-479.

Getz, D. (1989). Special Events. Defining the Product. Tourism Management, June.

Getz, D. (1997). Event Management and Event Tourism. New York: Cognitizant

Granovetter, M. (1985). Economic Action and Social Structure: The problem of Embeddedness. American Journal of Sociology, Vol. 91(3), pp. 481-510.

Grönroos, C. (2006). What Can Service Logic Offer Marketing Theory? In Lush, R.F., \& Vargo, S.L. (Eds.), The Service-Dominant Logic of Marketing: Dialog, Debate, and Directions, pp. 339-353. Armonk, NY: ME Sharpe.

Gulati, R. (1999). Network Location and Learning: The Influence of Network Resources and Firm Capabilities on Alliance Formation. Strategic Management Journal, Vol. 20(5), pp. 397-420.

Gulati, R.; Nohria, N. \& Zaheer, A. (2000). Strategic networks. Strategi Management Journal, Special Issue, Vol. 21, pp. 203-215.

Gulati, R., N. Nohria and A. Zaheer (2006). Strategic Networks. In Dietger Hahn and Bernard Taylor (Eds). Strategische Unternehmungsplanung Strategische 
Unternehmungsführung Stand und Entwicklungstendenzen, DOI: 10.1007/3-54030763-X_15. Springer Link. Pp. 293-309.

Gummeson, E. (2006). Many-to-Many marketing as Grand Theory. In Lush, R.F., \& Vargo, S.L. (Eds.), The Service-Dominant Logic of Marketing: Dialog, Debate, and Directions, Armonk, NY: ME Sharpe, pp. 339-353.

Gundlach, G.T.; Achrol, R.S. \& Mentzer, J.T. (1995). The Structure of Commitment in Exchange. Journal of Marketing, Vol. 59(January), pp. 78-92.

Gummeson, E. (2002) Total Relationship Marketing. Oxford, UK: Butterworth-Heinemann.

Gunn, C. (1988). Vacationscape. Designing Tourist Regions, 2nd.ed. New York: Van Nostrand Reinhold.

Heide, J.B. \& John, G. (1988). The Role of Dependence Balancing in Safe Guarding Transaction-Specific Assets in Conventional Channels. Journal of Marketing, Vol. 52(10, January), pp. 20-35.

Henneberg, S.C.; Pardo, C., Mouzas, S. \& Naudé, P. (2005). Value Dimensions and Strategies in Dyadic "Key Relationship Programmes", Dealing with Dualities. Proceedings on the 21st IMP Conference, Rotterdam.

Hill, C.W. \& Jones, T.M. (1992). Stakeholder-Agency Theory. Journal of Management Studies, Vol. 29, pp. 131-154.

Holbrook, M.B. \& Hirschmann, E.C. (1982). The Experiental Aspects of Consumption: Fantasies, Feelings and Fun. Journal of Consumer Research, Vol. 9(2)1, pp. 32-139.

Holt, D.B. (1995). How Consumers Consume: A Typology of Consumption Practices, Journal of Consumer Research, Vol. 22(June), pp. 1-16.

Håkansson, H. (1982). International Marketing and Purchasing of Industrial goods: An Interaction Approach. Chichester: John Wiley \& Sons.

Kim, K. \& Frazier, G.L. (1997). Measurement of Dstributor Cmmitment in Idustrial Cannels of Dstribution. J Bus Research;40(2), pp. 139-54.

Kumar, N.; Scheer, L.K. \& Steenkamp, J.B.E.M. (1995). The Efects of Prceived Iterdependence on Daler Atitudes. Journal of Marketing Research (August);32, pp. 348-56.

Lovelock, C. (1981). Why Marketing Management Needs to be Different for Services. In Marketing of Services. Donnelly, J. \& George, W. (Eds.),. American Marketing Association: Chicago, pp. 5-9.

March, J. \& Simon, H. (1958). Organizations. New York: Wiley.

Mason, R.O. \& Mitroff, I.I. (1981). Challenging Strategic Planning Assumptions. New York: Wiley.

Moorman, C.; Deshpande, R. \& Zaltman, G. (1993). Factors Affecting Trust in Market Research Elationships. Journal of Marketing (January). ;57, pp. 81-101.

Morgan, R.M. \& Hunt, S.D. (1994). The commitment and trust theory of relationship marketing. Journal of Marketing, Vol. 58(July), pp. 20-38.

Movondo, F.T. \& Rodrigo, E.M. (2001). The Effects of Relationship Dimensions on Interpersonal and Interorganisational Commitment in Organisations Conduction Business between Australia and China. Journal of Business Research, Vol. 55, pp. 111-121.

Mummalaneni, V. \& Wilson, D.T. (1991) The Influence of a Close Personal Relationship Between a Buyer and a Seller on the Long-Term Future of their Role Relationship. 
Pennsylvania State University Park: Institute for the Study of Business Markets, (report:4-1991).

Möller, K. and A. Rajala (2007). Rise of Strategic Nets - New modes of value creation. Industrial Marketing Management 36, pp. 895-908.

Möller, K.E. \& Wilson, D.T. (1995). Business Marketing: An Interaction and Network Perspective. Boston: Kluwer.

Nahapiet, J. \& Ghoshal, S. (1998). Social Capital, intellectual Capital and Organizational Advantage. Academy of Management Review, Vol. 23(2), pp. 242-267.

Nielson, C.C. \& Wilson, E.J. (1994). Interorganizational Cooperation in Buyer-Seller Relationships. Paper presented at the Second Research Conference on Relationship Marketing, Relationship Marketing: Theory, Methods and Applications, Emory University.

Noordewier, T.G, \& Nevin, J.G. JR. (1990). Performance Outcomes of Purchasing Arrangements in Industrial Buyer-Vendor Relationships. Journal of Marketing, Vol 54(October), pp. 80-93.

Pesämaa, O. \& Hair, J.F. Jr. (2007). More Than a Friendship is Required: An Empirical Test of Cooperative Firm Strategies. Management Decision, Vol. 45(3), pp. 602-615.

Pitts, B.G. \& Stotlar, D.K. (2002), Fundamentals of Sport Marketing, 2nd ed. Morgantown, WV: Fitness Information Technology.

Porter, M.E. (1980). Competitive Strategy. Free Press: New York.

Portes, A. (1998). Social Capital: Its Origins and Applications in Modern Sociology. Annual Review of Sociology, Vol. 24, pp. 1-24.

Prebensen, N.K. (2007). Exploring Tourists' Images of a Distant Destination, Tourism Management, Vol. 28, pp. 747-456.

Prebensen, N.K. (2007). Investing in an Event - The Case of a Sledge Dog Race in Norway "The Finnmarksløpet". Event Management, Vol. 11(3), pp. 99-108.

Prebensen, N.K. (2010). Value Creation Through Stakeholder Participation: A Case Study of an Event in the High North. Event Management, Vol. 14, pp. 37-52.

Rotter, J.B. (1967). A New Scale for Measurement of Interpersonal Trust. Journal of Personality, Vol. 35(4), pp. 651-665.

Rowley, T.J. (1997). Moving Beyond dyadic Ties: A Network Theory of Stakeholder Influences. The Academy of Management, Vol. 22(4), pp. 887-910.

Rylander, D.; Strutton, D. \& Pelton, L.E. (1997). Toward a Synthesized Framework ofRelational Commitment: Implications for Marketing Channel Theory and Practice. Journal of Marketing Theory Practice, Vol. 5(1), pp. 58-71.

Schaaf, P. (1997). Sports Marketing: It's Not Just a Game Anymore. Amherst, MA: Prometheus Books.

Terpsta, V. \& David, K. (1985). The Cultural Environment of International Business. Cincinnati: South-Western Publishing.

Trail, G.; Fink, J. \& Anderson, D. (2003), Sport Spectator Consumption Behavior. Sports Marketing Quarterly, Vol. 12 (1), pp. 8-15.

Ulaga, W. (2003). Capturing Value Creation in Business Relationships: A Customer Perspective. Industrial Marketing Management, Vol. 32, pp. 677-693.

Ulaga, W. \& Eggert, A. (2006). Value-Based Differentiation in Business Relationships: Gaining and Sustaining Key Supplier Status. Journal of Marketing, Vol. 70, pp. 119-136. 
Uzzi, B. (1997). Social Structure and Competition in Interfirm Networks: The Paradox of Embeddedness. Administrative Science Quarterly, Vol. 42(1), pp. 35-67.

Van Limburg, B. (2009). Innovation in pop festivals by cocreation. Event Management, Vol. 12, pp. 105-117.

Vargo, S.L. \& Lush, R.F. (2004). Evolving to a New Dominant Logic for Marketing. Journal of Marketing, Vol. 68, pp. 1-17.

Vargo, S.L. \& Lush, R.F. (2006). Service-Dominant Logic: What it is, What it is Not, What it Might be. In R.F. Lush \&. Vargo, S.L (Eds.), The service-dominant logic of marketing: Dialog, debate, and directions, Amonk, NY: M.E. Sharpe, pp. 43-56.

Wernerfelt, B. (1984). A Resource Based View of The Firm. Strategic Management Journal, Vol. 5(2), pp. 171-180.

Wilkinson, L. (2008). Business Relating Business: Managing Organisational Relations and Networks. London: Edward Elgar.

Yoon, J.; Baker, M.R. \& Ko, J-W. (1994). Interpersonal Attachment and Organizational Commitment: Subgroup hypothesis revisited. Human Relations, Vol. 47(3), pp. 329351.

Zaheer, A.; McEvily, B. \& Perrone, V. (1998). Does Trust matter? Exploring the Effects of Interorganizational and Interpersonal Trust on Performance. Organization Science, Vol. 9(2), pp. 141-59. 


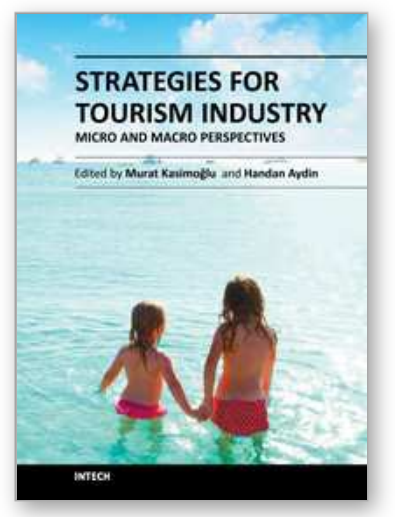

\author{
Strategies for Tourism Industry - Micro and Macro Perspectives \\ Edited by Dr. Murat Kasimoglu
}

ISBN 978-953-51-0566-4

Hard cover, 392 pages

Publisher InTech

Published online 20, April, 2012

Published in print edition April, 2012

Today, it is considered good business practice for tourism industries to support their micro and macro environment by means of strategic perspectives. This is necessary because we cannot contemplate companies existing without their environment. If companies do not involve themselves in such undertakings, they are in danger of isolating themselves from the shareholder. That, in turn, creates a problem for mobilizing new ideas and receiving feedback from their environment. In this respect, the contributions of academics from international level together with the private sector and business managers are eagerly awaited on topics and sub-topics within Strategies for Tourism Industry - Micro and Macro Perspectives.

\title{
How to reference
}

In order to correctly reference this scholarly work, feel free to copy and paste the following:

Nina Katrine Prebensen (2012). Value Creation in Experience-Based Networks: A Case Study of Sport-Events in Europe, Strategies for Tourism Industry - Micro and Macro Perspectives, Dr. Murat Kasimoglu (Ed.), ISBN: 978-953-51-0566-4, InTech, Available from: http://www.intechopen.com/books/strategies-for-tourism-industrymicro-and-macro-perspectives/value-creation-in-experience-based-networks-a-case-study-of-sport-events-ineurope

\section{INTECH}

open science | open minds

\section{InTech Europe}

University Campus STeP Ri

Slavka Krautzeka 83/A

51000 Rijeka, Croatia

Phone: +385 (51) 770447

Fax: +385 (51) 686166

www.intechopen.com

\section{InTech China}

Unit 405, Office Block, Hotel Equatorial Shanghai

No.65, Yan An Road (West), Shanghai, 200040, China

中国上海市延安西路65号上海国际贵都大饭店办公楼405单元

Phone: +86-21-62489820

Fax: $+86-21-62489821$ 
(C) 2012 The Author(s). Licensee IntechOpen. This is an open access article distributed under the terms of the Creative Commons Attribution 3.0 License, which permits unrestricted use, distribution, and reproduction in any medium, provided the original work is properly cited. 